\title{
Genotype-environment interaction and phenotypic stability for girth growth and rubber yield of Hevea clones in São Paulo State, Brazil
}

\author{
Paulo de Souza Gonçalves ${ }^{1}$, Nelson Bortoletto ${ }^{2}$, Antonio Lúcio Mello Martins ${ }^{3}$, \\ Reginaldo Brito da Costa ${ }^{4}$ and Paulo Boller Gallo ${ }^{5}$ \\ ${ }^{1}$ APTA, Instituto Agronômico, Programa Seringueira, Campinas, São Paulo, Brazil. \\ ${ }^{2}$ APTA Regional do Noroeste Paulista, Votuporanga, São Paulo, Brazil. \\ ${ }^{3}$ APTA Regional do Centro Norte, Pindorama, São Paulo, Brazil. \\ ${ }^{4}$ UCDB Programa Desenvolvimento Local, Campo Grande, Mato Grosso do Sul, Brazil. \\ ${ }^{5}$ APTA Regional do Nordeste Paulista, Mococa, São Paulo, Brazil
}

\begin{abstract}
The best-yielding, best vigour and most stable Hevea clones are identified by growing clones in different environments. However, research on the stability in Hevea brasiliensis (Willd. Adr. ex Juss.) Muell.-Arg. is scarce. The objectives of this work were to assess genotype-environment interaction and determine stable genotypes. Stability analysis were performed on results for girth growth and rubber yield of seven clones from five comparative trials conducted over 10 years (girth growth) and four years (rubber yield) in São Paulo State, Brazil. Stability was estimated using the Eberhart and Russell (1966) method. Year by location and location variability were the dominant sources of interactions. The stability analysis identified GT 1 and IAN 873 as the most stable clones for girth growth and rubber yield respectively since their regression coefficients were almost the unity $(\beta=1)$ and they had one of the lowest deviations from regressions $\left(\bar{S}_{\mathrm{di}}^{2}\right)$. Their coefficient of determination $\left(\mathrm{R}^{2}\right)$ was as high as $89.5 \%$ and $89.8 \%$ confirming their stability. In contrast, clones such as PB 235, PR 261, and RRIM 701 for girth growth and clones such as GT 1 for rubber yield with regression coefficients greater than one were regarded as sensitive to environment changes.
\end{abstract}

Key words: Hevea brasiliensis, rubber tree, coefficient of determination, stability parameters.

Received: June 6, 2003; Accepted: August 25, 2003.

\section{Introduction}

Genotype-environment interaction in crops such as the rubber tree [Hevea brasiliensis (Willd. Adr. ex Juss.) Muell.-Arg.] is the differential response of genotypes to changing environmental conditions. Such interactions complicate testing and selection in tree breeding programs and result in reduced overall genetic gain. The literature on genotype-environment interaction in Hevea is not extensive. Its effects have been recognized in Malaysia (Tan, 1995), Sri Lanka (Jayasekera, 1983; Jayasekera and Karunasekera, 1994 and Jayasekera et al., 1977, 1984), Nigéria (Onokopise et al., 1986) Indonésia (Daslin et al., 1986), India (Menattoor et al., 1991) and more recently in Brazil (Gonçalves et al.; 1990, 1991, 1998 abc, 1999 and, Costa et al., 2000).

Send corresponce to Paulo de Souza Gonçalves. Instituto Agronômico, Caixa Postal 28, 13001-970 Campinas, SP, Brazi. E-mail: paulog@iac.sp.gov.br.
In Hevea, productivity performance is represented mainly by girth growth and yield stability. Breeders search for genotypes that show stability vigor and high yield over the years and locations. In general, a genotype is considered stable when its performance across environments does not deviate from the average performance of a group of standard genotypes.

Several methods have been proposed to analyze genotype $\mathrm{x}$ environment interactions and phenotypic stability (Lin et al., 1986; Becker and Leon, 1988; Piepho, 1998; Truberg and Huhn, 2000). These methods can be divided into two major groups, univariate and multivariate stability statistics (Lin et al., 1986). Joint regression is the most popular among the univariate methods because of its simplicity of calculation and application (Becker and Leon, 1988). Joint regression provides a conceptual model for genotypic stability (Becker and Leon, 1988;. Romagosa and Fox, 1993). The regression of the yield or girth of an individual genotype on environment mean yields is determined. The 
genotype $\mathrm{x}$ environment interaction from analysis of variance is portioned into heterogeneity of regression coefficients $\left(\beta_{i}\right)$ and the sum of deviations $\left(\Sigma \bar{S}^{2} d_{i}\right)$ from regressions. Finlay and Wilkinson (1963) defined a genotype with regression coefficient equal to zero $\left(\beta_{i}=0\right)$ as stable, while Eberhart and Russell (1966) defined a genotype with $\beta_{i}=1$ to be stable. Most biometricians consider $\bar{S}^{2} d_{i}$ as stability parameter rather than $\beta_{i}$ (Eberhart and Russell, 1966; Becker and Leon, 1988). According to the joint regression model, a stable genotype is one with a high mean yield, $\beta_{i}=1$ and $\bar{S}^{2} d_{i}=0$ (Eberhart and Russell, 1966).

In Brazil, Kalil Filho (1982) was the first researcher to use Eberhart and Russell (1966) as a stability method. He studied temporal yielding, where the environments were represented by different months and years through an environmental index obtained by the mean performance of all the genotypes in each month and year. Later, Gonçalves et al. (1992, 1999), using the same stability method, examined the magnitude of the genotype $\mathrm{x}$ environment interaction on girth growth of Hevea at different ages, searching for clone stability and genetic gains.

The objectives of this study are (1) to examine the magnitude of genotype $\mathrm{x}$ environment interaction in ten-year girth growth and four-year rubber yield in Hevea clones, (2) to characterize these clones for stability.

\section{Material and Methods}

\section{Plant material}

One Brazilian, three Indonesian and three Malaysian genotypes (clones) were used in this study (Table 1). The Brazilian clone IAN 873 was developed by the breeding program of the former Instituto Agronômico do Norte, nowdays, Embrapa Western Amazon. The Indonesian clones comprised GT 1, PR 261 and PR 255 from Gondang Tapen and Proefstation voor Rubber stations. The Malaysia cultivars consisted of RRIM 701, RRIM 600 and PB 235 from Rubber Research Institute of Malaysian and Prang Besar private rubber plantation. Clones PB 235, GT 1, RRIM 600 and IAN 873 are recommended production clones, whereas RRIM 701, PR 255 and PR 261 are used as parents in local rubber breeding programs. The rubber clones were budded onto established rootstocks (Tjir $1 \mathrm{x}$ Tjir 16) in the nursery. One-year-old rootstock seedlings raised in nurseries were used to budgraft clonal materials. Budgrafting was made on December, 1989. The successful budgrafts were uprooted and planted in polyethylene bags. After the first flush of leaves developed, the plants were established in the field.

\section{Experimental locations}

The clones were grown in a total of five contrasting test environments for ten years in the plateau region of São Paulo State (Table 2). These locations represent the most
Table 1 - Origin and individual genealogy of seven Hevea genotypes (clones) tested at different locations in São Paulo State, Brazil.

\begin{tabular}{lcc}
\hline Clones $^{1}$ & Parentage & Origin \\
\hline GT 1 & Primary clone & Indonésia \\
PR 261 & Tjir $1 \times$ PR 107 & Indonésia \\
PR 255 & Tjir $1 \times$ PR 107 & Indonésia \\
IAN 873 & PB 86 x FA 1717 & Brazil \\
RRIM 701 & 44/553 x RRIM 501 & Malaysia \\
PB 235 & PB 5/51 x PB S 78 & Malaysia \\
RRIM 600 & Tjir $1 \times$ PB 69 & Malaysia \\
\hline
\end{tabular}

${ }^{1}$ GT - Godang Tapen; RRIM - Rubber Research Institute of Malaysia; IAN - Instituto Agronômico do Norte; PR - Proefstation voor Rubber; PB - Prang Besar; Tjir - Tjirandji; FA - Ford Acre.

important continental climate non-traditional rubber production area. The experimental design at each test location was randomized complete blocks with three replications. Thirty plants were used in each plot in all locations except Matão. At Matão, a larger plot size of forty plants was used. Plots consisted of five rows of six or eight plants each. Trees were spaced $8.00 \mathrm{~m}$ between and $2.50 \mathrm{~m}$ within rows, resulting in approximately 500 trees ha.

\section{Measurements}

The girth growth and rubber yield of each tree were measured. In the first year diameter was recorded because plants were too small to measure the girth. Measurements were converted into girth assuming that plants were measured $0.50 \mathrm{~m}$ above ground level by a slide caliper. The other girth measurements were recorded $1.20 \mathrm{~m}$ from the highest point of the bud union.

At the end of the sixth year all the trees that reached a girth of $45.0 \mathrm{~cm}$ or more were opened for tapping at a height of $1.20 \mathrm{~m}$ above the highest point of the bud union for annual latex production. Attempts were to record 10 girth measurements and four annual yields. The latex extracted from the panel followed a half-spiral four-daily tapping system (seven tapping/month) for 11 months/years. Yield was recorded on the days when normal tapping, which starts around 7:30 AM, was possible. After tapping, latex was allowed to collect in plastic cups provided for each recording tree. Once the latex was flow stopped, rubber was coagulated in the cup itself by adding $2 \%$ acetic acid solution and stirring it well. The coagulated rubber in each cup was then made into a "biscuit" which was dried ranged by wire tied in each tree for about 30 days, was weighed and the dry rubber content for each tree was recorded.

\section{Statistical analysis}

A combined three-factor analysis of variance was performed on data collected for all locations and years using the statistical model 
Table 2 - Details of experimental locations and planting dates from five different test locations where seven Hevea clones were evaluated in São Paulo State, Brazil.

\begin{tabular}{|c|c|c|c|c|c|}
\hline \multirow[t]{2}{*}{ Remarks } & \multicolumn{5}{|c|}{ Locations } \\
\hline & Mococa & Ribeirão Preto & Votuporanga & Indiana & Matão \\
\hline Year of planting & 1989 & 1989 & 1989 & 1989 & 1989 \\
\hline Planting material & Budded stumps & Budded stumps & Budded stumps & Budded stumps & Budded Stumps \\
\hline Spacing (m) & $7.00 \times 3.00$ & $7.00 \times 3.00$ & $7.00 \times 3.00$ & $7.00 \times 3.00$ & $8.00 \times 2.50$ \\
\hline \multirow[t]{2}{*}{ Planting density } & 5 rows $x 6$ trees & 5 rows $x 6$ trees & 5 rows $\times 8$ trees & 5 rows $x 6$ trees & 5 rows $x 8$ trees \\
\hline & 30 trees $/$ plot & 30 trees/plot & 40 trees/plot & 30 trees/plot & 40 trees/plot \\
\hline Design of experiment & $\mathrm{RBD}^{1}$ & RBD & RBD & RBD & RBD \\
\hline Numbers of replications & 3 & 3 & 3 & 3 & 4 \\
\hline Total area (ha) & 1.3 & 1.3 & 1.76 & 1.3 & 2.2 \\
\hline Elevation (m) (mean sea level) & 665 & 467 & 450 & 621 & 551 \\
\hline Latitude (S) & $21^{\circ} 28^{\prime}$ & $22^{\circ} 11^{\prime}$ & $20^{\circ} 25^{\prime}$ & $32^{\circ} 21^{\prime}$ & $21^{\circ} 25^{\prime}$ \\
\hline Longitude (EE) & $47^{\circ} 01^{\prime}$ & $47^{\circ} 48^{\prime}$ & $49^{\circ} 50^{\prime}$ & $51^{\circ} 30^{\prime}$ & $48^{\circ} 25^{\prime}$ \\
\hline Temperature (annual mean) & $24.5^{\circ} \mathrm{C}$ & $29.10^{\circ} \mathrm{C}$ & $22.3^{\circ} \mathrm{C}$ & $28.10^{\circ} \mathrm{C}$ & $21.0^{\circ} \mathrm{C}$ \\
\hline Annual rainfall (mm) (mean annual) & 1500 & 1534 & 1480 & 1257 & 1430 \\
\hline Soil type ${ }^{2}$ & Eutrustox & Kandiudox & Paleudalf & Paleudalf & Paleudox \\
\hline Terrain & Flat to undulating & Flat to undulating & Falt & Flat & Flat \\
\hline Year of planting & 1989 & 1989 & 1989 & 1989 & 1989 \\
\hline
\end{tabular}

${ }^{1}$ Randomized block design.

$$
\begin{aligned}
& Y_{i j k l}=\mathrm{u}+g_{i}+p_{i}+t_{k}+(g p)_{i j}+(g t)_{j k}+(t p)_{i k}+ \\
& (g p t)_{i j k}+e_{i j k l}
\end{aligned}
$$

where $\mathrm{Y}_{i j k l}$ is the $i^{\text {th }}$ observation on the $l^{\text {th }}$ clone in $j^{\text {th }}$ location in the $k^{\text {th }}$ year. The first four terms are the mean and the main effects of genotypes (clones), locations and years. The next three terms are the first order interactions, then the second order interaction and finally the microenvironmental deviation within locations and years. It is usually assumed that genotypes (clones) and locations are fixed effects and years random effects, so that the model is a mixed effects model.

All analysis were performed using the GENES computer program, Windows version, 2001 (Cruz, 2001). The method of Eberhart and Russell (1966) was used in this study to characterize genotypic stability. The following linear regression model was used:

$$
Y_{i j}=\mu+\beta_{i} I_{j}+\delta_{i j}+\bar{\varepsilon}_{i j}
$$

where $Y_{i j}$ is the mean of the clone $i^{\text {th }}$ at the location $j$; $\mu$ is the general mean of clone $i ; \beta_{i}$ is the regression coefficient of the $i^{\text {th }}$ clone at the location index which measures the response of this clone to varying location; $I_{j}$ is the environmental index which is defined as the mean deviation of all clones at a given location from the overall mean; $\delta_{i j}$ is the deviation from regression of the $i^{\text {th }}$ clone in the $j^{\text {th }}$ location; $\bar{\varepsilon}_{i j}$ is the mean of experimental error.

Two stability parameters were calculated: (a) the regression coefficient, which is the regression of the performance of each clone under different locations on the environment, means over all the genotypes. This is estimated according to Sing and Chaudhary (1979) as follows:

$$
\beta_{i}=\frac{\sum_{j} Y_{i j} I_{j}}{\sum_{j} I_{j}^{2}}
$$

where $\sum_{\text {of squares }} Y_{i j} I_{j}$ is the sum of products and $\sum_{j} I_{j}^{2}$ is the sum
o

(b) Mean square deviations $\left(\bar{S}_{d}^{2}\right)$ from linear regression,

$$
=\frac{\sum_{j} \delta_{i j}^{2}}{(s-2)}-\frac{\bar{S}_{d}^{2}}{r}
$$

where $\sum_{j} \delta_{i j}^{2}=\left[\sum_{j} Y_{i j}^{2}-\frac{Y_{i}^{2}}{t}\right]-\frac{\left(\sum_{j} Y_{i j} I_{j}\right)^{2}}{\sum_{j} I_{j}^{2}}$ and $S_{e}^{2}=$ the estimate of pooled error.

The contribution of locations in generating interactions was studied using a method developed by Burdon (1977). It considers growth in different locations as separate traits and calculates the genetic correlations between pairs of locations.

\section{Results and Discussion}

The results of the combined analysis of girth growth and rubber yield across locations and years are given in Ta- 
ble 3. Effects of years, locations, genotypes and their interactions except for genotype year $(\mathrm{G} x \mathrm{Y})$ for rubber yield $(p<0.05)$ were highly significant $(p<0.01)$. Out of the total variance, a larger portion of variation was caused by the locations effect and their interaction with years ( $\mathrm{S} \times \mathrm{Y}$ ), followed by the years effect. The former accounted for about $17.0 \%$ while $14.5 \%$ could be attributed to the latter. The highly significant differences for $\mathrm{S}$ and $\mathrm{Y}(\mathrm{p}<0.01)$ indicated the fluctuations of genotypes in their responses to the different environments.

There was also tremendous change in girth growth ranks of the genotypes across locations (Table 4). Similarly, a recent study (Gonçalves et al., 1999) undertaken on the girth growth stability at six years also revealed very high fluctuations in the growing environments of São Paulo State. This shows the difficulties encountered by breeders in selecting new genotypes (clones) for release; these difficulties arise mainly from the masking effects of variable environments. Pham and Kang (1988) indicated that genotype $\mathrm{x}$ environment interactions minimize the usefulness of genotypes by confounding their yield performance. Thus, it is important to study in depth the vigor levels, adaptation patterns and stability of genotypes in multi-location trials. Becker and Leon (1988) also indicated that assessment of stability across many locations and years could increase both repeatability and heritability of important traits.

The genotype means for girth growth and rubber yield, their ranks and differences among genotypes means for the seven genotypes tested across five (girth growth) and four (rubber yield) locations over the tenth and fourth years, respectively, are presented in Table 4 . The highest girth growth of $62.67 \mathrm{~cm}$ was obtained from PB 235 clone at Votuporanga, while the lowest was from RRIM 701 at Mococa. Across the locations, however, PB 235 surpassed

Table 3 - Analysis of variance of girth growth $(\mathrm{cm})$ and rubber yield for seven Hevea genotypes (clones) tested at five locations in São Paulo State, Brazil.

\begin{tabular}{lcccccc}
\hline \multirow{2}{*}{$\begin{array}{l}\text { Sources of } \\
\text { variation }\end{array}$} & \multicolumn{2}{c}{ Girth growth } & & \multicolumn{2}{c}{ Rubber yield } \\
\cline { 2 - 3 } \cline { 6 - 7 } & D.F. & M.S. & & D.F. & M.S. \\
\hline Replications (P/Y) & 100 & 5.0317 & & 32 & 19.7662 \\
Genotypes (G) & 6 & $219.3001^{* *}$ & & 6 & $2,408.9117^{* *}$ \\
Years (Y) & 9 & $33,506.2674^{* *}$ & & 3 & $916.8731^{* *}$ \\
Locations (L) & 4 & $4,220.9545^{* *}$ & & 3 & $14,991.8680^{* *}$ \\
G x Y & 54 & $8.1058^{* *}$ & & 18 & $26.6794^{*}$ \\
G x L & 24 & $67.2242^{* *}$ & & 18 & $298.1749^{* *}$ \\
Y x L & 36 & $111.7173^{* *}$ & & 9 & $1,089.6314^{* *}$ \\
G x Y x L & 216 & $4.2320^{* *}$ & & 54 & $64.5435^{*}$ \\
Residual (mean) & 600 & 3.7666 & & 192 & 18.7875 \\
Média & & 32.1829 & & 36.2198 \\
CV(\%) & & 6.0305 & &
\end{tabular}

* and $* *$ significant for $\mathrm{p}<0.05$ and $\mathrm{p}<0.01$, respectively.

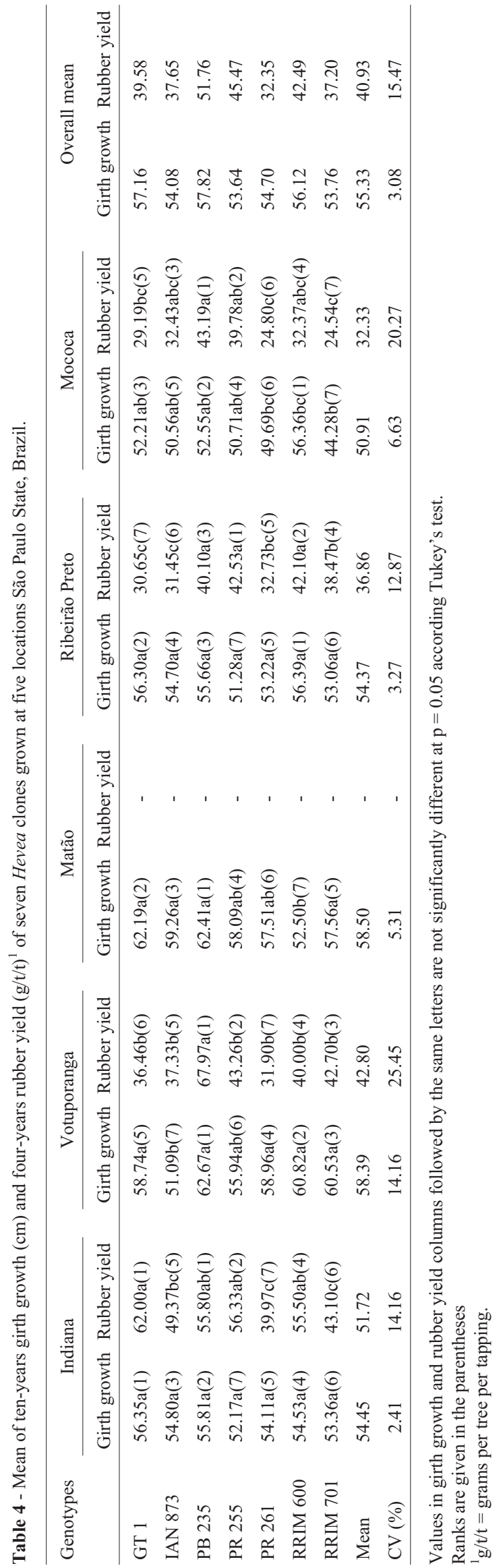


all other genotypes with a mean girth growth of $57.16 \mathrm{~cm}$. Its mean girth growth exceeded that of PB 255 by about $5 \%$ indicating its high vigour and good adaptability to the Hevea-growing environment of São Paulo.

The partitioning of variance components revealed that environment factors both predictable (locations) and unpredictable (year) were important sources of variation (Table 3). When genotype $\mathrm{x}$ environment is due to variation in predictable environment factors, Hevea breeders have the alternatives of either developing specific varieties for different environments (location, soil types, management systems, etc.) or broadly adapted varieties that can perform well under variable conditions. However, when genotype $\mathrm{x}$ environment interaction results from variation in unpredictable environmental factors, such as year to year variation in rainfall distribution, as in the case in this study, the breeder needs to develop stable genotypes that can perform reasonably well under a range of conditions. Such breeding strategies can assist the rubber producer in risk avoidance. Ceccarelli (1994) and Piepho (1998) indicated that producers perceive yield stability as the most important socio economic aim to minimize crop failure, especially in marginal environments.

The stability analysis conducted for ten-year girth growth and four-year rubber yield at five locations of the study is presented in Table 5, and revealed that the clones differ significantly for both characters. The clone $\mathrm{x}$ location interaction component was further partitioned into linear (locations and clones x locations) and non-linear (pooled deviations) components. Mean squares for both of these components were tested against pooled error mean square. The linear component was higly significant, indicating that the predictable-components shared with clone $\mathrm{x}$ location interactions. Preponderance of linear clone $\mathrm{x}$ location interaction is of great practical importance, implying that there are differences among linear regression coefficients for each clone.
Table 5 - Analysis of variance for stability parameter for seven Hevea genotypes (clones) of ten years girth growth and rubber yield tested at five and four different locations, respectively São Paulo State, Brazil.

\begin{tabular}{lrcccc}
\hline \multirow{2}{*}{ Source of variation } & \multicolumn{2}{c}{ Girth growth } & & \multicolumn{2}{c}{ Rubber yield } \\
\cline { 2 - 3 } \cline { 5 - 6 } & d.f. & M.S. & & d.f. & M.S. \\
\hline Clones & 6 & $43.6412^{*}$ & & 6 & $480.8276^{* *}$ \\
Locations & 28 & $1,402.8983^{* *}$ & & 21 & $310.8017^{* *}$ \\
(clone x location) & & & & \\
Locations (linear) & 1 & $354.7185^{* *}$ & & 1 & $4416.9052^{* *}$ \\
Clones x locations & 6 & $40.1737^{* *}$ & & 6 & $72.0071^{* *}$ \\
(linear) & & & & & \\
Pooled deviation & 21 & $14.4541^{* *}$ & & 14 & $119.8492^{* *}$ \\
GT 1 & 3 & 5.6365 & & 2 & $117.6850^{* *}$ \\
IAN 873 & 3 & $37.6206^{* *}$ & & 2 & 31.1334 \\
PB 235 & 3 & 2.4694 & & 2 & $462.0978^{* *}$ \\
PR 255 & 3 & 6.5224 & & 2 & 30.6365 \\
PR 261 & 3 & 1.5828 & & 2 & 23.6860 \\
RRIM 600 & 3 & $37.4819^{* *}$ & & 2 & $58.1025^{*}$ \\
RRIM 701 & 3 & 9.8653 & & 2 & $115.6029^{* *}$ \\
Pooled error & 60 & 5.4635 & & 48 & 14.2419 \\
\hline
\end{tabular}

* and ** significant for $\mathrm{p}<0.05$ and $\mathrm{p}<0.01$, respectively.

The stability parameters for all clones are given in Table 6. Eberhart and Russell (1966) emphasized the need of considering both linear $\left(\beta_{i}\right)$ and non-linear $\left(\bar{S}^{2} d_{i}\right)$ components of genotype environment interactions in judging the stability of a genotype. A wide adaptability genotype was defined as one with $\beta_{i}=1.0$ and high stability as one with $\bar{S}^{2} d_{i}=0$. In this study values for the regression coefficient $\left(\beta_{i}\right)$ ranged from 0.0723 (RRIM 600) to 1.8608 (RRIM 701) for girth growth. For rubber yield the range for $\beta_{i}$ was 0.6875 (PR 261) to 1.7196 (GT 1). Plotting all clonal means $\mathrm{x}$ location means with the corresponding regression lines illustrates the differential reactions of clones to changing environments (Figure 1).

Table 6 - Estimates of stability and adaptability parameters of the traits girth growth $(\mathrm{cm})$ and rubber yield $(\mathrm{g} / \mathrm{t} / \mathrm{t})^{1}$ for seven Hevea clones grown at five locations São Paulo State, Brazil.

\begin{tabular}{|c|c|c|c|c|c|c|c|c|}
\hline \multirow[t]{2}{*}{ Genotypes } & \multicolumn{2}{|c|}{${ }^{2} x_{i}$} & \multicolumn{2}{|c|}{${ }^{3} \hat{\beta}_{i}$} & \multicolumn{2}{|c|}{${ }^{4} \bar{S}^{2} d_{i}$} & \multicolumn{2}{|c|}{${ }^{5} R_{i}^{2}(\%)$} \\
\hline & Girth growth & Rubber yield & Girth growth & Rubber yield & Girth growth & Rubber yield & Girth growth & Rubber yield \\
\hline GT 1 & 57.1573 & 39.5608 & 1.0874 & $1.7196^{* *}$ & 0.0577 & $34.4810^{* *}$ & 89.5169 & 88.7984 \\
\hline IAN 873 & 54.0813 & 37.6558 & $0.5314^{*}$ & 0.9299 & $10.7190 * *$ & 5.6305 & 23.4013 & 89.7563 \\
\hline PB 235 & 57.8187 & 51.7633 & 1.3899 & 0.9260 & -0.9980 & $149.2853 * *$ & 96.9549 & 36.9281 \\
\hline PR 255 & 53.6367 & 45.4625 & 0.9262 & 0.8266 & 0.3530 & 5.4649 & 84.2595 & 87.5558 \\
\hline PR 261 & 54.6973 & 32.3525 & 1.1319 & $0.6875^{*}$ & -1.2936 & 3.1480 & 97.0541 & 86.2946 \\
\hline RRIM 600 & 56.1661 & 42.4942 & $0.0723 * *$ & 1.0665 & 10.6728 & $14.6202 *$ & 0.5651 & 86.0644 \\
\hline RRIM 701 & 53.7553 & 37.2025 & $1.8608 * *$ & 0.8439 & 1.4673 & $33.7869 * *$ & 93.4576 & 66.0275 \\
\hline
\end{tabular}

* and ** significant for $\mathrm{p}<0.05$ and $\mathrm{p}<0.01$, respectively; ${ }^{1} \mathrm{~g} / \mathrm{t} / \mathrm{t}=$ grams per tree per tapping. ${ }^{2} x_{i}=$ mean; $3 \hat{\beta}_{i}=$ mean regression coefficient; ${ }^{4} \bar{S}^{2} d_{i}=$ deviation from regression; ${ }^{5} R_{i}^{2} \%=$ coefficient of determination. 
The regression coefficient of clones GT 1, PB 235, PR 261 and PR 255 for girth growth was non-significantly different from the unity $\left(\beta_{i}=1\right)$ and had a small deviation from regression $\left(\bar{S}^{2} d_{i}\right)$ and thus possessed fair stability. Finlay and Wilkinson (1963) and Eberhart and Russell (1966) stated that genotypes with high mean yield, regression coefficient equal to the unity $(\beta=1)$ and deviation from regression as small as possible $\left(\bar{S}^{2} d_{i}=0\right)$ are considered stable. Accordingly, GT 1 and IAN 873 were the most stable clones for girth growth and rubber yield, respectively, since their regression coefficients were almost equal to the unity and they had the lowest deviations from regression. Their coefficients of determination, $\mathrm{R}^{2}$ (Pinthus, 1973 ), were as high as $89.5 \%$ and $89.8 \%$ confirming their stability. In contrast, the clones PB 235, PR 261 and RRIM 701 for girth growth and the clones GT 1 for rubber yield, with regression coefficients greater than one, were regarded as sensitive to environmental changes.
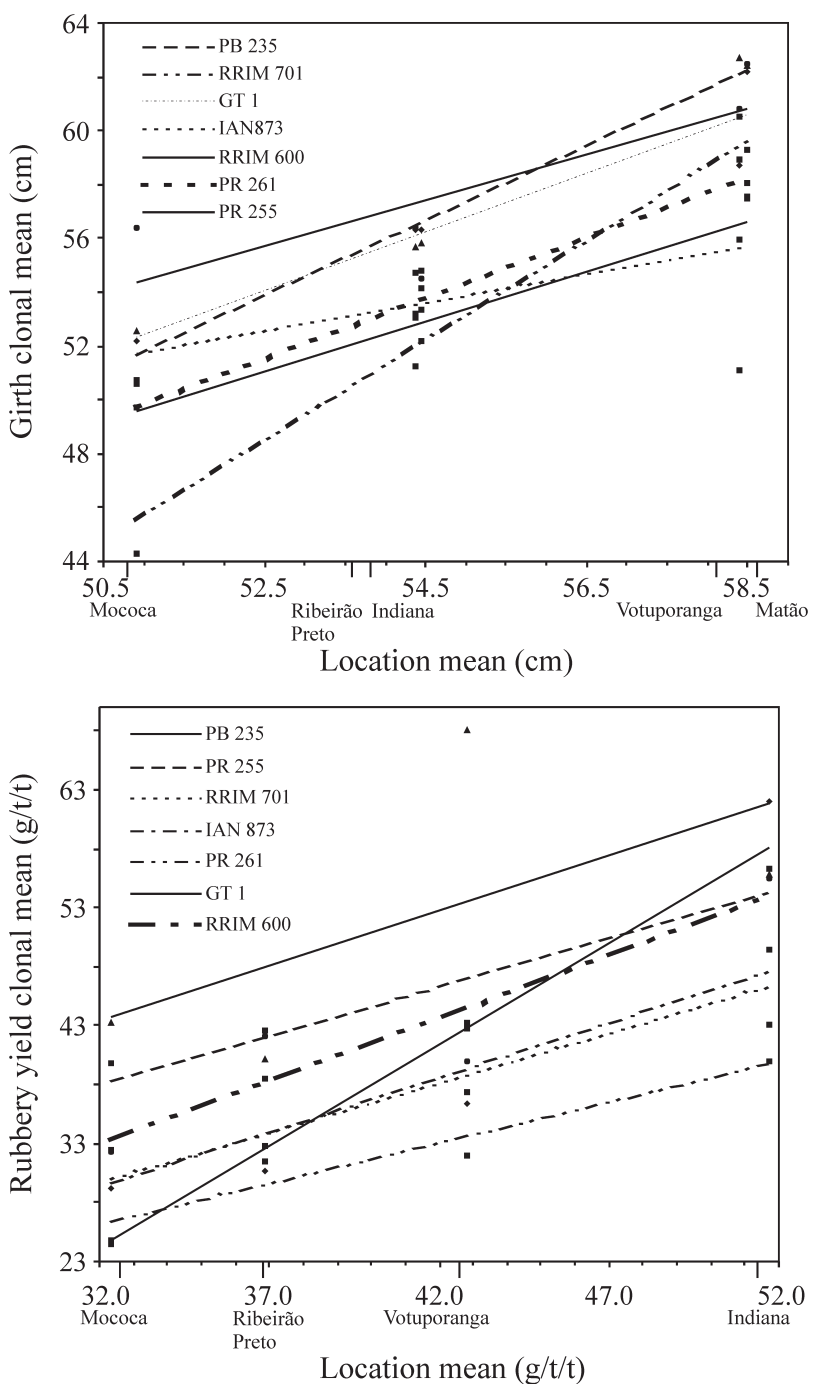

Figure 1 - Plot of girth growth and rubber yield clonal means for seven clones against site means with corresponding regression lines.
Figure 2 shows a representation of the genotype regression coefficients plotted against the means. The genotype PB $235\left(\beta_{i}=1.39\right)$ had a regression coefficient for girth growth greater than the unity and was highly vigorous and high yielding, so it may be characterized as suitable for specific adaptation in favorable environments. The locally adapted cultivars had regression coefficients close to the unity, had above average yields and may, therefore, be characterized as well adapted to all environments. These genotypes also had the smallest deviations from regression and, hence, may be regarded as stable genotypes. The genotypes PR 261 and RRIM 701 that had regression coefficients of less than unity and below average rubber yields, indicating that they offer a greater resistance to environmental change and are specially adapted to poor environments.

The regression coefficient measures the "relative" performance of the clone. Clair and Kleinschimit, (1986) emphasizes that in forest tree breeding, this information is useful to distinguish clones for specific environments, but if all environments tested are in one planting zone, and each represents the same proportion of area to be planted, then this information is irrelevant. Selection on the overall mean is all that is necessary to assure the largest overall gains. Therefore clones GT 1 and IAN 873 could be considered superior in future breeding programs in order to incorporate stability for vigour and rubber yield. According to Singh and Gupta (1988) it is possible that stable genotypes carry genes for stability, useful in breeding programs because it facilitates economic production.

Table 7 shows the correlation matrix among locations. Girth growth of the trees at Mococa was significartly
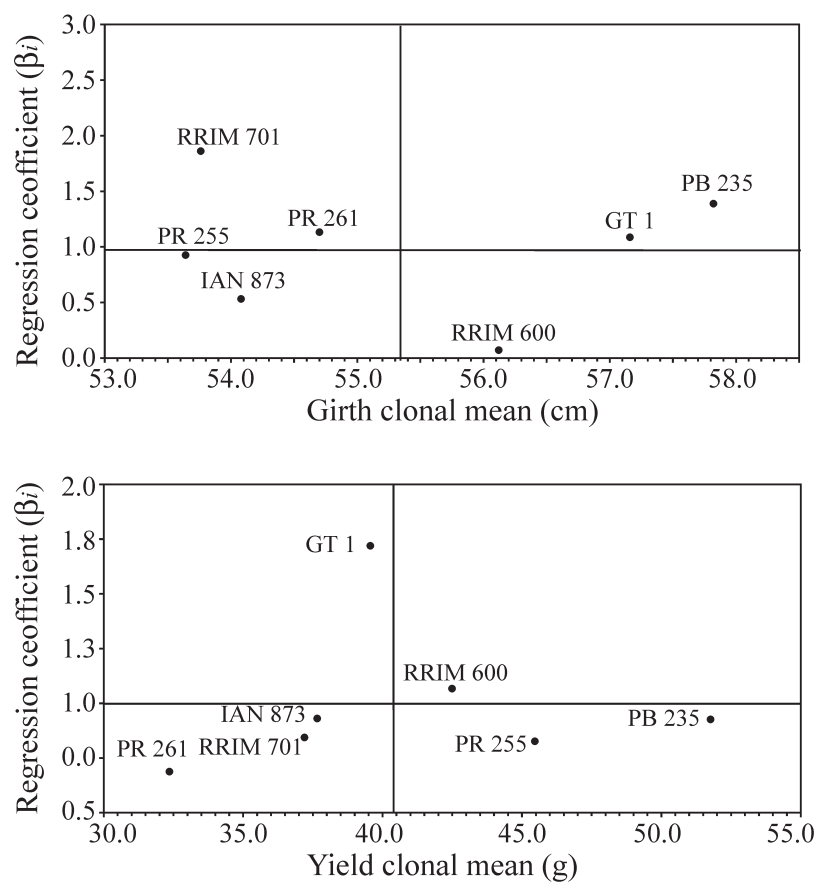

Figure 2 - Plot of deviation from regression coefficient against girth and yield clonal means in a stability study of seven Hevea clones. 
Table 7 - Genetic correlation coefficients between locations for girth growth and rubber yield (between parenthesis) in São Paulo State, Brazil.

\begin{tabular}{lcccc}
\hline Locations & Ribeirão Preto & Indiana & Votuporanga & Matão \\
\hline Mococa & 0.623981 n.s. & 0.422400 n.s. & $0.104463 n . s$. & $0.783443^{*}$ \\
& $(0.528938$ n.s. $)$ & $(0.600499$ n.s. $)$ & $(0.758129 *)$ & - \\
Ribeirão Preto & & $0.889579^{* *}$ & 0.288359 n.s. & $0.888974^{* *}$ \\
& & $(0.175431$ n.s. $)$ & $(0.506696 n$.s. $)$ & - \\
Indiana & & $0.219663 n . s$. & $0.760962^{*}$ \\
& & & $(0.305830$ n.s. $)$ & - \\
Votuporanga & & & 0.379341 n.s. \\
& & & & - \\
\hline
\end{tabular}

n.s.: no significant; $*$ and ${ }^{* *}$ : significant for $\mathrm{p}<0.05$ and $\mathrm{p}<0.01$, respectively.

correlated with Matão. Therefore the girth growth of Mococa was not necessarily a good indication of vigour. Only at Ribeirão Preto did tree girth growth show very high and stable statistically significant correlations with the girth growth of Indiana and Matão. There was also correlation among tree girth growth between Indiana and Matão. On the other hand, rubber yield were not necessarily a good indicator of correlation among locations. Only Mococa showed statistically significant correlations with Votuporanga.

Finally the following major findings can be summarized from this study: (1) GT 1 and IAN 873 were the most stable clones for girth growth and rubber yield, respectively, and are thus recommended for commercial release in São Paulo. (2) The significant genotype-environment interactions and the change in rank of genotypes (clones) across environments suggest a breeding strategy of specifically adopted genotypes in homogenously grouped environment. (3) Whenever new varieties are proposed for commercial release, information on genotype-environment interactions and stability, clearly indicating their specific and/or general adaptations, needs to be available to the user.

\section{Acknowledgements}

The authors thank the State of São Paulo Research Foundation (FAPESP) and National Council for Scientific and Technological Development $(\mathrm{CNPq})$ for their financial support for this study.

\section{References}

Becker HC and Leon J (1988) Stability analysis in plant breeding, Plant Breed 101:1-23.

Brasil. Ministério da Agricultura. Centro Nacional de Ensino e Pesquisas Agronômicas. Comissão de Solos (1960). Levantamento de reconhecimento dos solos do Estado de São Paulo, Boletim 12, Rio Janeiro, pp 634.

Burdon RD (1977) Genetic correlation as a concept for studying genotype-environment interaction in forest tree breeding. Silvae Genet 26:168-175.

Ceccareli S (1994) Specific adaptation and breeding for marginal conditions. Euphytica 77:205-109.
Clair JB and Kleinschmit J (1986) Genotype-environment interaction and stability in ten-year height growth of Norway Spruce clones (Picea abies karts). Silvae Genetica 35:177186.

Costa RB da, Resende MDV de, Araújo AJ de, Gonçalves P de S and Martins ALM (2000) Genotype-environmental interaction and the number of test locations for the genetic improvement of rubber tree (Hevea) in São Paulo State, Brazil, Genet Mol Biol 23:179-187.

Cruz CD (2001) Programa genes: versão windows aplicativo computacional em genética e estatística, Viçosa: UFV, 2001, $641 \mathrm{p}$.

Daslin A, Bailaki A, Danakusuma TM and Haeruman MS (1986) Genotypes $x$ environment interaction in rubber and their implications in clonal selection. Bull Perkaretan 4:23-28.

Eberhart SA and Russell WW (1966) Stability parameters for comparing varieties. Crop Sci 6:36-40.

Finlay KW and Wilkinson GN (1963) Adaptation in a plant breeding programme. Aust J Res 14:742-754.

Gonçalves P de S, Bataglia OC, Santos ER dos, Ortolani AA, Segnini Jr I and Shikasho EH (1998a) Gowth trends, genotype $\mathrm{x}$ environment intreraction and genetic gains in six year old rubber tree clones (Hevea) in São Paulo State. Genet Mol Biol 21:115-122.

Gonçalves P de S, Bortoletto N, Fonseca F da S, Bataglia OC and Ortolani AA (1998c) Early selection for gowth vigour in rubber tree genotype in Nortwestern São Paulo State (Brazil). Genet Mol Biol 21:515-521.

Gonçalves P de S, Cardoso M, Colombo CA and Ortolani AA (1991) Clones de Hevea: Influência dos fatores ambientais na produção e recomendação para plantio, Boletim Técnico 138, Instituto Agronômico, Campinas.

Gonçalves P de S, Cardoso M, Colombo CA, Ortolani AA, Martins ALM and Santos ICI (1990) Variabilidade genética da produção anual da seringueira: estimativas de parâmetros genéticos e estudo da interação genótipo x ambiente. Bragantia 49:305-320.

Gonçalves P de S, Cardoso M, Santos ICI dos, Martins ALM, Ortolani AA and Colombo CA (1992) Selection of Hevea mother tree adapted to unpredictable annual climatic varibility. Braz J Genet 15:137-147.

Gonçalves P de S, Fujihara AK, Ortolani AA, Bataglia OC, Bortoletto N and Segnini Jr I (1999) Phenotypic stability and genetic gains in six-year girth growth of Hevea clones. Pesq Agropec Brasil 34:1223-1232. 
Gonçalves P de S, Martins ALM, Bortoletto N, Bataglia OC and Silva MA (2003) Age trends in genetic control of production traits in Hevea. Crop Breeding and Applied Biotecnology 3:163-172.

Gonçalves P de S, Segnini Jr I, Ortolani AA, Brioschi AP, Landell MG and Souza SR de (1998b) Components of variance and genotype $\mathrm{x}$ environment interaction for annual girth increment in rubber tree. Pesq Agrop Bras 33:1329-1337.

Jayasekera NEM (1983) A basis for selecting Hevea clones stable to umpredictable agroclimate variability. Silvae Genet 32:181-185.

Jayasekera NEM and Karumasekera KB (1984) Effect of environment on clonal performance with respect to early vigour and yield in Hevea brasiliensis Proceedings of the IRRDB meeting on Hevea Phisiology Explotation and Breeding. IRRDB, Montpellier, pp 250-255.

Jayasekera NEM, Karunasekera KB and Kearsey MJ (1994) Genetics of production traits in Hevea brasiliensis (rubber) I. Changes in genetic control with age. Heredity 73:650-656.

Jayasekera NEM, Samaranayake P and Karunasekera KB (1977) Initial studies on the nature on genotype environment interaction in some Hevea cultivars. J Rubber Res Inst Sri Lanka 54:33-39.

Kalil Filho AN (1982) Potencial de produtividade e estabilidade fenótipica na caracterização de clones de seringueira (Hevea spp.). Dissertação de mestrado, USP-ESALQ, Piracicaba, $95 \mathrm{p}$.

Lin CS, Binns MR and Levkowitch LP (1986) Stability analysis: where do we stand? Crop Sci 26:894-900.
Menattoor RJ, Vinod KK, Krushnakumar AK, Seturaj MR, Potty SN and Sinha RR (1991) Clones x environmental interaction during early growth phase of Hevea brasiliensis I. Clonal stability on girth. Indian J Nat Rubber Res 4:51-58.

Onokpise OU, Olapade O and Mekaki HU (1986) Genotype x environment interaction in Hevea brasiliensis (Müell.-Arg.). Indian J Genet 46:06-511.

Pham HN and Kang MS (1988) Interrelationships among respectability of several stability statistics estimated from international maize trials. Crop Sci 28:925-928.

Piepho HP (1998) Methods for comparing the yield stability of cropping system - a review. J Agron Crop Sci 190:193-21.

Pinthus JM (1973) Estimate of genotype value: a proposed method. Euphitica 22:121-123.

Romagosa I and Fox PN (1993) Genotype-environment interaction and adaptation. In: Hayward MD, Bosemark NO and Romagosa I (eds) Plant Breeding: Principles and prospects. Chapman and Hall, London, p 373-390.

Singh RK and Chaudhary BD (1977) Biometical methods in quantitative genetic analysis. Kalayni Publishers, New Delhi, 304 p.

Singh SV and Gupta PK (1988) Phenotypic stability for tuber yield potato (Solanum tuberosum L.). Indian Journal of Genetics and Plant breeding 48:1223-1232.

Tan H (1995) Genotype x environment interaction studies in rubber (Hevea) clones. J Nat Rubber Res 10:63-76.

Truberg M and Huhn HG (2000) Contributions to the analysis of genotype-environment interactions: comparison of different parametric and non-parametric tests for interaction. J Agron Crop Sci 185:267-274.

Editor: Marcio de Castro Silva Filho 